\section{On the geometry and allometry of big- buttressed trees - a challenge for forest monitoring: new insights from 3D-modeling with terrestrial laser scanning}

\author{
Nils Nölke ${ }^{(1)}$, Lutz Fehrmann ${ }^{(1)}$, I Nengah Surati Jaya ${ }^{(2)}$, \\ Tatang Tiryana $^{(2)}$, Dominik Seidel ${ }^{(1)}$, Christoph Kleinn ${ }^{(1)}$
}

In many old-growth natural and close-to-natural forest types, notably in humid tropical forests, a relatively small number of very tall trees contribute considerably to stand basal area and biomass. Such trees often show distinct buttress roots with irregular non-convex shapes. Buttresses are complex structures in the lowest stem section, where most tree biomass is located. The methods used to assess the diameter of buttressed trees have a large impact on the determination of volume and biomass, as well as on the resulting estimates of the aboveground carbon stock in tropical forests. As the measurement of diameter at breast height $(D B H$ at $1.3 \mathrm{~m})$ is not feasible in such conditions, the diameter above buttress $(D A B)$, where the cylindrical bole of the tree begins, is usually measured and included as an independent variable in biomass models. We conducted a methodological study aimed at determining the volume and biomass of individual buttressed trees belonging to several tropical species by the application of terrestrial laser scanning (TLS). The geometry and allometry of the buttresses, as well as the change with height along the stem in buttress volume and cross-sectional area were analyzed. Our results suggest that the relationship between cross-sectional areas at $D A B$ height $\left(A_{D A B}\right)$ and the actual tree basal area measured at $1.3 \mathrm{~m}$ height is relatively strong $\left(R^{2}=0.87\right)$ across a range of different species, buttress morphologies and tree dimensions. Furthermore, the change in stem cross-sectional area with tree height was surprisingly similar and smooth. Despite the small number of trees sampled, the methodological approach used in this study provided new insights on the very irregular geometry of buttressed trees. Our results may help improving the volume and biomass models for buttressed trees, that are crucial contributors to carbon stocks in tropical forests.

Keywords: Biomass, Morphology, Volume, Form Factor

\section{Introduction}

One of the most meaningful attributes used to describe forests both as a resource and as an ecosystem is biomass density per unit area. Nondestructive measurements of tree biomass are not possible - at least if the term "measurement" is used in its generic sense. Therefore, models are established based on

destructively sampled trees to estimate total biomass. Tree variables commonly used for such models are the diameter at breast height ( $D B H$, measured at $1.3 \mathrm{~m}$ height) or $D B H$ in combination with total tree height. These allometric relationships (from the ancient Greek word " $\alpha \lambda \lambda \circ \varsigma$ " = "other") are commonly modeled as power functions (Niklas

$\square$ (1) Chair of Forest Inventory and Remote Sensing, Universität Göttingen, Büsgenweg 5, D-37075 Göttingen (Germany); (2) Division of Forestry Planning, Department of Forest Management, Faculty of Forestry, Bogor Agricultural University (Indonesia)

@ Nils Nölke (nnoelke@gwdg.de)

Received: Sep 19, 2014 - Accepted: Dec 22, 2014

Citation: Nölke N, Fehrmann L, Surati Jaya IN, Tiryana T, Seidel D, Kleinn C, 2015. On the geometry and allometry of big-buttressed trees - a challenge for forest monitoring: new insights from 3D-modeling with terrestrial laser scanning. iForest 8: 574-581 [online 201503-02] URL: http://www.sisef.it/iforest/contents/?id=ifor1449-007

Communicated by: Matteo Garbarino
1994, West et al. 1999a, Zianis \& Mencuccini 2004, Pilli et al. 2006, Fehrmann \& Kleinn 2006) of the form $M=a D b$, where $M$ is the mass of dry matter, $D$ is the diameter, $b$ is the allometric scaling factor and $a$ is a coefficient determining the allometric intercept (Parresol 1999). The general model formulation also complies with assumptions of process models in plant allometry that are based on considerations on the hydraulic architecture and structural design of vascular plants and derive a particular scaling exponent of 8/3 (West et al. 1997, 1999a, 1999b, Enquist 2002, Niklas 2004, 2013). Total tree biomass is expected to scale proportionally to the conducting tissue that determines the metabolic rate.

The predicted biomass value, however, is not to be understood as a "measurement", but rather as "model-based estimation", carrying not only measurement errors (introduced by the measurement of the input variables to the model used) but also model errors (Clark \& Kellner 2012). In many old-growth natural and close-to-natural forest types, in particular tropical forests, the relatively few very large trees fix a large amount of carbon (Stephenson et al. 2014) and contribute a considerable share to the stand basal area and total biomass: "Large trees drive forest aboveground biomass variation in moist lowland forests across the tropics" (Slik et al. 2010).

In tropical forests the largest proportion of buttressed trees is usually among the emergent trees in the upper crown layer. These huge trees frequently show very irregular non-convex shapes (Chapman et al. 1998, Mehedi et al. 2012, Cushman et al. 2014). Clark (2002) reports for a Costarican lowland rain forest that about $52 \%$ of the stands' above ground woody biomass was constituted by trees whose diameter needed to be measured above stem irregularities. A study in southwest China shows that the percentage of buttressed trees is highest in the larger diameter classes (He et al. 2013). Buttresses are complex features that are regarded as an adaptation to poor tropical soils, enabling trees to form a flat root system in the upper, nutrient richer soil layers while maintaining their mechanical stability and anchorage (Richards 1952, Richter 1984, Ennos 1993, Crook et al. 1997, Newbery et al. 2009, Niklas 2013). Usually Dipterocarpaceae, Ligumninosae and Sterculiaceae show a greater tendency to produce buttresses than other tree species. Physiologically, buttress roots are the result of secondary xylem formed on the upper side of lateral roots. In very large trees the buttresses may extend to heights of more than $9 \mathrm{~m}$. Early studies have already shown that the size and profile of buttresses vary considerably between species, while within species the de- 
velopment and morphology of buttressing often appears to follow a fairly fixed character (Richards 1952, Smith 1972, He et al. 2013).

The methods used to measure the diameter of buttressed trees have a large impact on the and consequently on the resulting estimates on aboveground carbon stocks in tropical forests (Clark \& Clark 2000). Measuring the $D B H$ of these trees is practically impossible and actually counterproductive, because a proper interpretation of such a measurement is not possible as of yet (Ngomanda et al 2012). Commonly, a diameter above buttress $(D A B)$ is measured where the cylindrical bole of the tree starts (Clark \& Clark 2000 Clark 2002, Basuki et al. 2009, Metcalf et al 2009). However, ignoring the buttressed part of the stem when determining total tree biomass and carbon stocks (e.g., by applying biomass models that are calibrated based on $D B H$ measurements) will lead to a considerable under-estimation (Nogueira et al. 2006 Cushman et al. 2014). This is a dilemma as there are no operational allometric models for buttressed trees, even though they are known to be one of the most important contributors to total biomass in many forests (Phillips et al. 2002, Henry et al. 2010) Even if buttressed trees are included in some general allometries (like e.g., Chave et al 2005), unbiased predictions could only be expected if the model is applied to a forest that has a similar proportion of buttressed trees as the calibration dataset

Hence the challenging shape of buttressed trees has long attracted the attention of fores researchers and ecologists and their morphology has been investigated by different techniques. The measurement of the crosssectional area for buttressed parts of the trunk with conventional techniques is difficult (Ngomanda et al. 2012) and precise volume estimates of the buttressed stem section for larger trees are rare and often based on destructive techniques (Nogueira et al 2006).

Terrestrial laser scanning (TLS), on the other hand, offers new possibilities to tackle determination of the volume and biomass,

the issue of buttress shape by providing a contactless and non-destructive approach to derive 3-dimensional point clouds of the stem surface that can be used as a basis to establish operational allometric models for buttressed trees. The application of terrestrial "close-range remote sensing" is not entirely new. For example, Dean (2003) presented a study where terrestrial photography was applied to assess the stem taper of buttressed trees. Moreover, a study on modeling irregularly shaped trees with TLS and photogrammetry was recently conducted in Central Africa (Bauwens 2013).

The overall goal of this study is to contribute to improving buttressed tree mensuration, in particular in the context of determining individual tree volume and biomass. We were interested in tree geometry and allometry of buttress variables and how buttress volume can be determined from variables that can realistically be measured in the field during standard forest monitoring projects. If multiplied with mean wood density the buttress volume can also be used to predict the biomass of respective stem sections. Further, in order to apply existing allometric biomass models that are based on $D B H$ or tree basal area at $1.3 \mathrm{~m}$ above the ground, our study evaluates whether these input variables could be modeled from $D A B$ measurements. For this study we scanned 12 huge buttressed trees of different species in the Botanical Garden of Bogor, Indonesia and analyzed the geometry of the buttresses, specifically investigating the change of the stem cross-sectional area and compactness over tree height for individual trees, as well as the common allometry of the buttresses over different species. Despite the relatively small number of sample trees does not allow general conclusions about buttress morphology in different species, our study does give valuable indications about the suitability of the methodological approach

\section{Material and methods}

\section{Study site}

Data were collected in the Bogor Botanical

Tab. 1 - List of the tree species sampled in this study.

\begin{tabular}{cllc}
\hline Tree (\#) & Species & Family & Height $(\mathbf{m})$ \\
\hline 1 & Koompassia excelsa & Fabaceae & 43.3 \\
2 & Ficus robusta & Moraceae & 39.9 \\
3 & Celtis rigescens & Cannabaceae & 48.3 \\
4 & Ficus albipila & Moraceae & 53.7 \\
5 & Shorea leprosula & Dipterocarpaceae & 51.7 \\
6 & Sterculia urceolata & Sterculiaceae & 34.0 \\
7 & Sterculia urceolata & Sterculiaceae & 39.1 \\
8 & Sterculia foetida & Sterculiaceae & 39.1 \\
9 & Ceiba pentandra & Bombacaceae & 32.6 \\
10 & Bombax ceiba & Bombacaceae & 34.1 \\
11 & Bombax valetonii & Bombacaceae & 30.3 \\
12 & Bombax valetonii & Bombacaceae & 30.1 \\
\hline
\end{tabular}

Garden (Kebun Raya Bogor) located in the city of Bogor, $60 \mathrm{~km}$ south of Jakarta, Indonesia (WGS 84: 6 $6^{\circ} 35^{\prime} 51^{\prime \prime} \mathrm{S}, 106^{\circ} 47^{\prime} 54^{\prime \prime}$ E). The Botanical Garden, founded in 1817 , has a total area of 87 hectares and contains a wide diversity of flora and fauna, approximately 15000 plant and tree species including huge buttressed trees. Due to the great variety of buttressed trees and the good visibility of their stems, the study site offers ideal conditions for prelimininary methodological studies.

We selected 12 different isolated buttressed trees spanning a variety of species, buttress heights and buttress geometric complexity (Tab. 1) and that were well visible by the terrestrial laser scans, since buttresses were not covered by climbers or other vegetation.

\section{Terrestrial laser scanning}

A phase-based terrestrial laser scanner (Zoller and Fröhlich Imager 5010c, Zoller and Fröhlich GmbH, Wangen i.A., Germany) was used to obtain three-dimensional point clouds. The single-scan resolution is defined by an angular step width of $0.036^{\circ}$ and a field-of-view of $360^{\circ}$ horizontally and $320^{\circ}$ vertically, resulting in up to 44 million measurements per scan. The wavelength of the emitted light beam is $1500 \mathrm{~nm}$. Scan settings were selected to provide a good balance of scan time and resolution; the time-consuming HDR image capture option was not used. A multiscan method was applied to retrieve a complete high-density point cloud of the bole and buttresses. In order to eliminate scan shadows up to 8 single scans from different positions were merged by placing artificial targets around the tree to co-register the single point clouds using ZF Laser Control 8.2 (Zoller and Fröhlich GmbH, Wangen i.A. Germany) with a maximum registration error of less than $6 \mathrm{~mm}$. The laser returns of single trees were extracted manually using Cyclone (Vers. 6, Leica Geosytems, Heerbrugg, Switzerland) and exported as .xyz file for further processing in $\mathrm{R}$ ( $\mathrm{R}$ Core Team 2013).

\section{Point cloud processing}

We used the Poisson Surface Reconstruction method (Kazhdan et al. 2006) for solid modeling based on the algorithm provided by the software MeshLab (Version 1.3.2). The meshes were applied to the whole trunk, but visual quality checks reveal that the resulting surface models do not describe the actual stem form very well, especially for very irregular trees. For an automated polygonal outline delineation of cross sections in different tree heights we applied the basic alpha shapes (Edelsbrunner \& Mücke 1994) based on the Delaunay triangulation to each polygon. However, this approach failed, especially in cases of high complex tree geometries, due to variation in point density. 
In order to determine accurate outlines of the non-convex cross sections at different heights for those trees that show more complex buttress morphology, we separated the point clouds in continuous thin layers ("discs") of $5 \mathrm{~cm}$ height, according to $z$ values to the upper end of buttresses. Above buttresses the distance between layers was increased to $50 \mathrm{~cm}$ up to the first strong branches. The lowermost disc was defined as the first cross-section that is free of ground elements (soil). The height of this disc was also used as reference for the determination of $D B H$ height $(1.3 \mathrm{~m})$.

Each layer of the point cloud was projected to a plane by removing the height information and a non-convex polygonal outline was delineated manually in standard GIS software (ARCGIS 10). Area, perimeter and shape metrics were calculated for each height from the outline delineated polygon. Further, we computed the convex hull and calculated its perimeter (Fig. 1). The latter is equal to a girth measured by tape around the buttresses at a specific height.

\section{Estimation of buttress volume}

From the delineated cross sections, the volume of each disc was calculated using the Smalian's formula (eqn. 1):

$$
v=\frac{A_{l}+A_{u}}{2} \cdot l
$$

where $A_{1}$ and $A_{\mathrm{u}}$ are the cross-sectional areas at the lower and upper side of each disk and $l$ is its height $(5 \mathrm{~cm}$ or $50 \mathrm{~cm}$, in our case). The single layer volumes were then accumulated over tree height, so that the actual volume up to each height interval is available.

\section{Characterization of buttress shape}

For each cross section we calculated the actual perimeter $P$ of the polygon, the crosssectional area $A$ and their ratio $(P / A)$. Moreover, we computed different metrics characterizing the shape of the cross sections. The isoperimetric quotient $Q$ is a measure of compactness and describes the ratio of the actual cross-sectional area $A$ and that of the circle of same perimeter $P$ (eqn. 2):

$$
Q=\frac{4 \pi A}{P^{2}}
$$

The end of buttresses refers to the height at which the isoperimetric index becomes $\geq$ 0.95 , indicating that the shape of the cross section is close to a circle (Fig. 2A). DAB was derived as diameter of a coextensive circle at $50 \mathrm{~cm}$ distance above the last buttress, which differed little from the average of two perpendicular direct measurements in the point clouds. There is no consistent definition of the height at which $D A B$ is measured (and neither a consistent definition of what is meant by the "top" of buttress); distances above the highest buttress of $0 \mathrm{~cm}$ (Ngo-

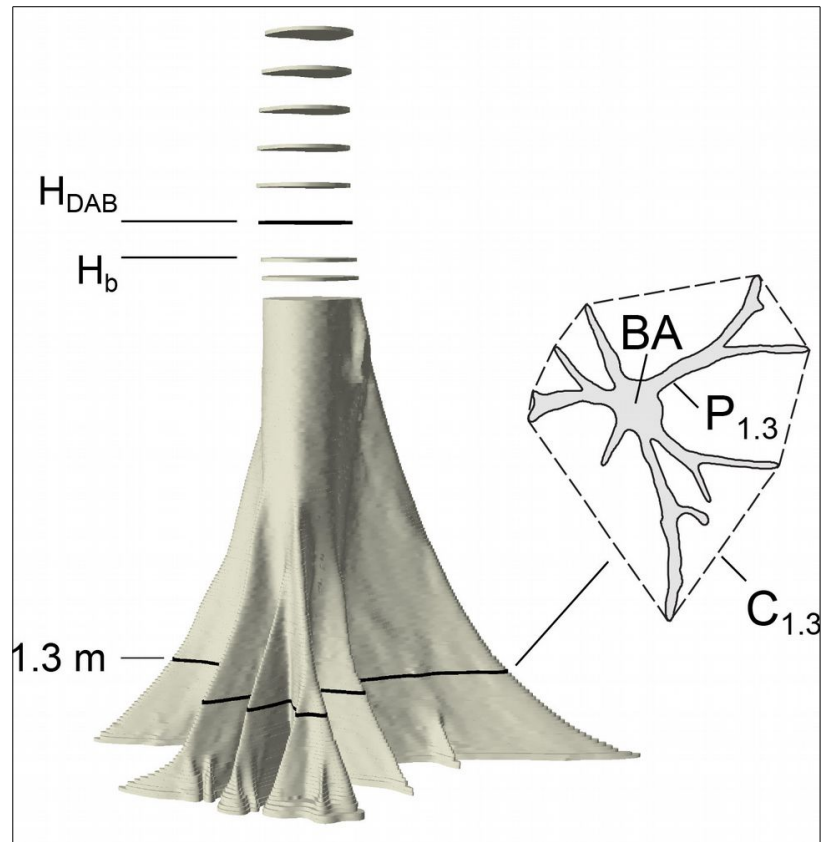

Fig. 1 - Graphical representation of the measurements taken on each sample tree analyzed. $H_{\mathrm{b}}$ is the maximum height of buttresses, $H_{\mathrm{DAB}}$ is the height of the diameter above buttresses $\left(H_{\mathrm{b}}+50 \mathrm{~cm}\right), A$ is the actual cross-sectional area (here at breast height), $P_{1.3}$ is the actual non-convex perimeter of the cross section at breast height and $C_{1.3}$ is the perimeter of the convex hull (dashed line).

manda et al. 2012, Saner et al. 2012), $20 \mathrm{~cm}$ (Mindawati et al. 2004), $30 \mathrm{~cm}$ (Basuki et al. 2009 citing FAO 2004), and $50 \mathrm{~cm}$ (Newbery et al. 2009) appear to be most common. However, the differences in diameter between these positions at the stem are mini$\mathrm{mal}$ in our data set. The perimeter of the convex hull in breast height $C_{1.3}$ is the girth measured above the buttresses at $1.3 \mathrm{~m}$ above the ground. The cross-sectional area at breast height is the tree basal area $(B A)$.

Based on the $D A B$ and its height we derived a buttress form factor $f_{\mathrm{b}}$ that describes the relation between the actual buttress volume $\left(V_{\mathrm{b}}\right)$ and the volume of a cylinder with a diameter equal to $D A B$ and a length equal to the $D A B$ measurement height $H_{\mathrm{DAB}}$ as follows (eqn. 3):

$$
f_{b}=\frac{V_{b}}{\frac{\pi}{4} D A B^{2} H_{D A B}}
$$

This form factor can be interpreted as an "indicator" for the potential under-estima-
A

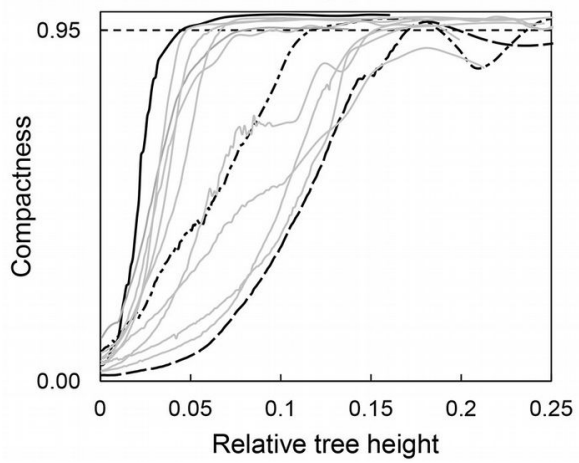

tion of the volume of the lower stem section in case that $D A B$ is used in the context of volume modeling.

In order to search for any relations among buttress variables that are of practical relevance, we fitted functions to describe the relation between the actual tree basal area, the cross-sectional area in $D A B$ height and the $C_{1.3}$. Acknowledging the small sample size, we did not focus on the best fit to the twelve data points, but we chose functions that make sense on first principles and that could extend over the full possible range of data. Power functions were fitted by linear regression on log-transformed data.

\section{Results}

In this study, the selected trees had very different dimensions and buttress morphologies, which was also reflected in the variables extracted. Tab. 2 thus gives an overview of the main characteristics of the 12 sample trees. The highest volume of the buttressed stem section was found for tree \#4 (Ficus al-

B

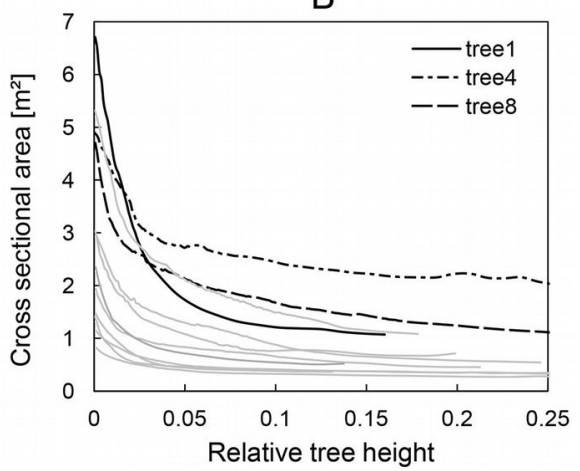

Fig. 2 - (A) Development of the isoperimetric quotient $(Q)$ over the relative tree height. (B) Development of the cross-sectional area over the relative tree height. 
Tab. 2 - Buttress characteristics obtained for each sampled tree. (BA): basal area; $\left(C_{1.3}\right)$ girth at $1.3 \mathrm{~m} ;\left(H_{\mathrm{DAB}}\right)$ : height of $D A B$ measurement; $(D A B)$ : diameter above buttress, $\left(V_{\mathrm{b}}\right)$ : buttress volume; $\left(f_{\mathrm{b}}\right)$ : buttress form factor.

\begin{tabular}{ccccccc}
\hline Tree & $\boldsymbol{B} \boldsymbol{A}\left(\mathbf{m}^{\mathbf{2}}\right)$ & $\boldsymbol{C}_{\mathbf{1 . 3}}(\mathbf{m})$ & $\boldsymbol{H}_{\mathbf{D A B}}(\mathbf{m})$ & $\boldsymbol{D} \boldsymbol{A} \boldsymbol{B}(\mathbf{c m})$ & $\boldsymbol{V}_{\mathbf{b}}\left(\mathbf{m}^{\mathbf{3}}\right)$ & $\boldsymbol{f}_{\mathbf{b}}$ \\
\hline 1 & 2.41 & 5.84 & 2.43 & 1.40 & 7.45 & 1.99 \\
2 & 1.49 & 8.78 & 7.07 & 0.88 & 7.97 & 1.85 \\
3 & 0.52 & 3.40 & 5.08 & 0.72 & 2.67 & 1.29 \\
4 & 3.15 & 10.18 & 7.18 & 1.66 & 20.50 & 1.32 \\
5 & 2.73 & 12.68 & 9.08 & 1.18 & 17.41 & 1.75 \\
6 & 0.88 & 6.17 & 7.23 & 0.81 & 5.10 & 1.37 \\
7 & 1.27 & 8.06 & 6.78 & 0.95 & 6.97 & 1.45 \\
8 & 2.35 & 13.38 & 7.03 & 1.32 & 13.67 & 1.42 \\
9 & 0.77 & 3.53 & 2.98 & 0.85 & 2.65 & 1.57 \\
10 & 0.43 & 3.27 & 2.63 & 0.67 & 1.24 & 1.34 \\
11 & 0.46 & 2.50 & 1.98 & 0.72 & 1.33 & 1.65 \\
12 & 0.52 & 2.83 & 2.98 & 0.73 & 1.72 & 1.38 \\
\hline
\end{tabular}

bipila) with $20.2 \mathrm{~m}^{3}$ up to a height of $7.18 \mathrm{~m}$ (and $38.2 \mathrm{~m}^{3}$ up to $15.5 \mathrm{~m}$ height). The total height of buttresses showed large variations. Some of the species analyzed were characterized by very tall buttresses of more than 8 m (e.g., Sterculia urceolata or Ficus robusta), while others tend to develop long lateral buttresses though quite low upwards (e.g., Koompassia excelsa or Bombax valetonii). Fig. 3 shows a perspective view of the delineated cross sections. Here the polygons are extruded to their original height of $5 \mathrm{~cm}$, giving an overview of the different buttress morphologies detected for the selected trees.

Fig. 4 shows how the cross sections change along the lowest $5-\mathrm{m}$ stem section for some sample trees: the geometries vary considerably, so that for many trees the stem could not be distinguished at the lowest cross sections.

Comparing the lower profiles of the depicted trees, the different morphology of lateral buttresses becomes obvious. While the horizontal projection of the laterals for tree \#4 (Ficus albipila) was characterized by a trapezoid form that narrows with increasing distance, the buttresses of tree \#8 (Sterculia foetida) were extremely thin.

In contrast to the different buttress morphologies of sample trees and their irregular cross sections, the development of the stem cross-sectional area over tree height was surprisingly similar and smooth. Fig. 2 shows the compactness (A, left) and the development of the cross-sectional area over the relative tree height $(\mathrm{B}$, right).

\section{Buttress allometry}

Despite the different morphology of buttressing across the tree species analyzed, the buttress form factor we derived for every individual tree showed a surprisingly small variability (Tab. 2). The mean form factor derived from the sample trees was $f_{\mathrm{b}}=1.53$ with a standard deviation of 0.23 . A simple generalized form factor may be applied to assess the volume of the buttressed lower stem section $V_{\mathrm{b}}$. Such calculation is based on two measurements, the $D A B$ and its height $H_{\text {DAB }}$ (eqn. 4):

$$
V_{b}=\frac{\pi}{4} D A B^{2} H_{D A B} f_{b}
$$

Another relation of practical relevance is that between the perimeter of the convex hull at $1.3 \mathrm{~m}$ height and the actual cross-sectional area. The former can be tape-measured as girth over the buttresses at breast height,

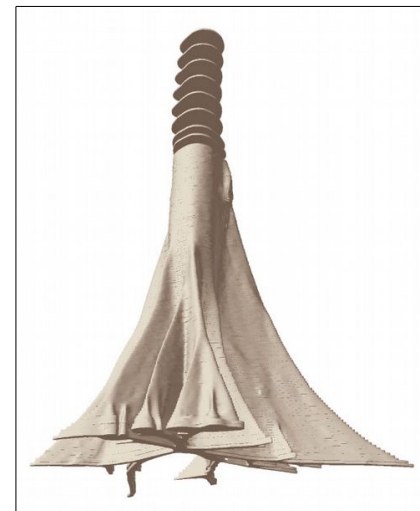

Tree 8 (Sterculia foetida)

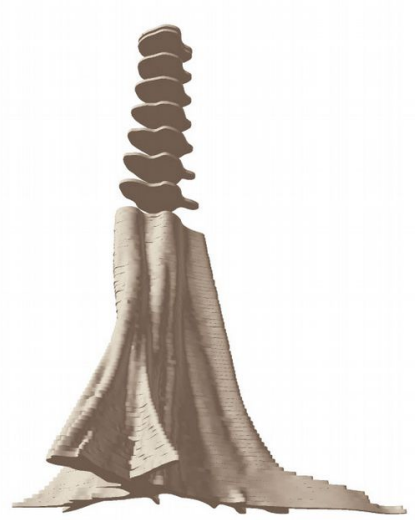

Tree 6 (Sterculia urceolata)
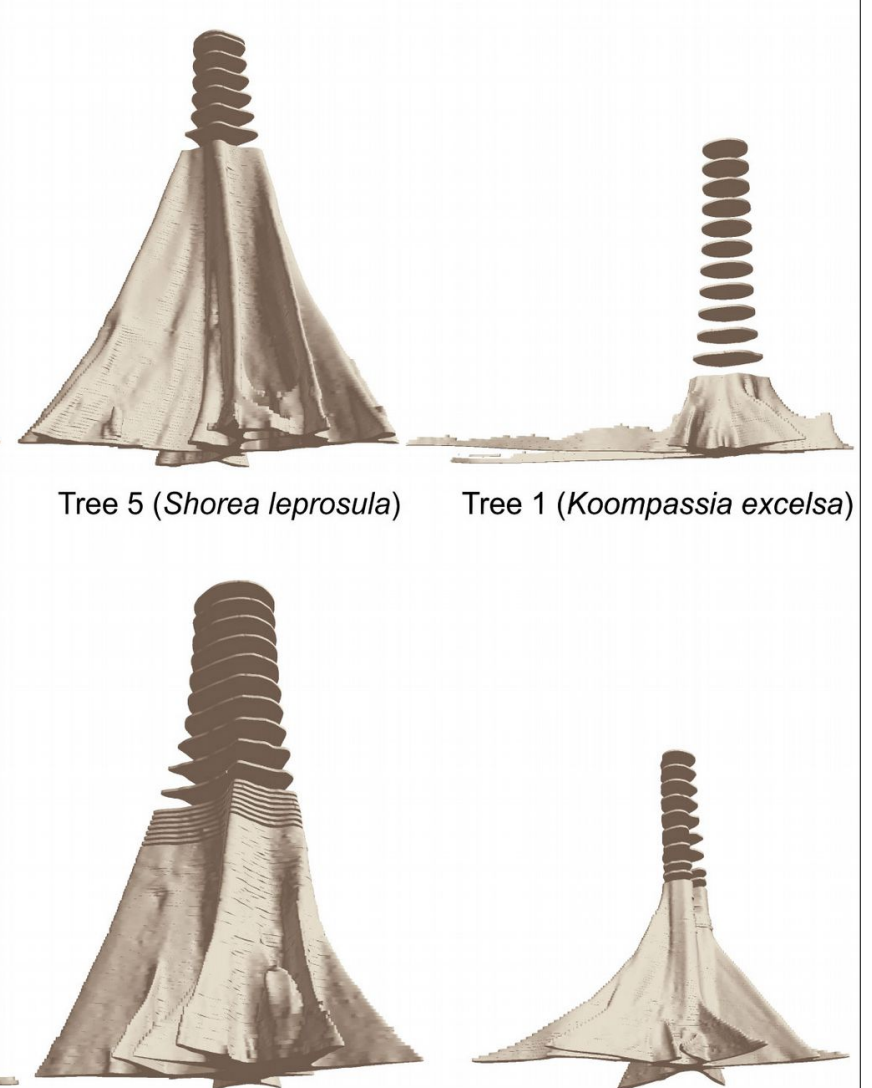

Tree 4 (Ficus albipila)
Fig. 3 - Examples of different buttress morphology of the sample trees (trees not in scale). 
Fig. 4 - Cross sections at different heights of tree \#1 (Koompassia excels), tree \#2 (Ficus robusta), tree \#4 (Ficus albipila), tree \#5 (Shorea leprosula), tree \#7 (Sterculia urceolata) and tree \#8 (Sterculia foetida). The dashed line at $1.3 \mathrm{~m}$ height represents the outline of the convex hull that could be tapemeasured as girth "around" butressess.

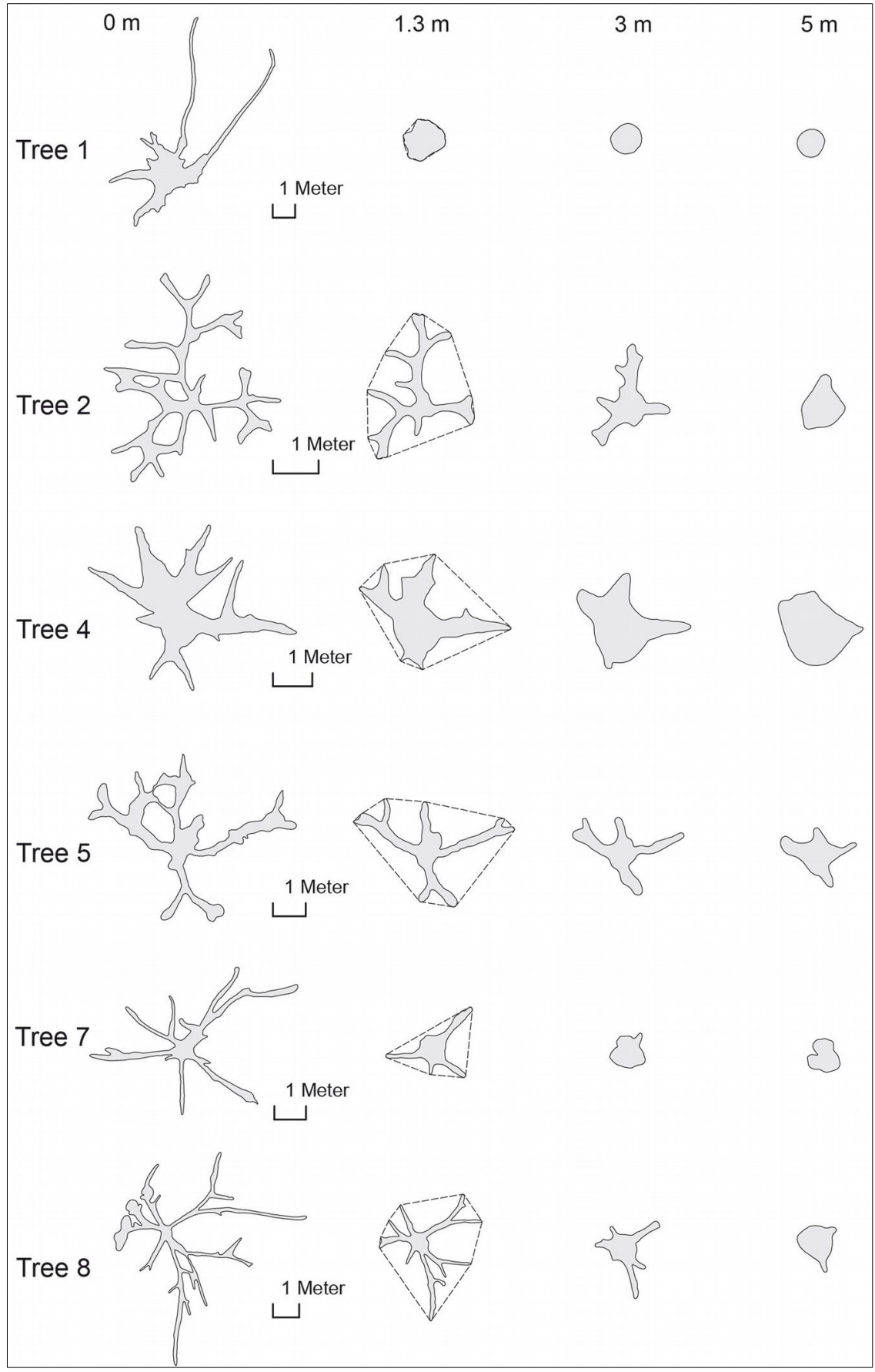

A

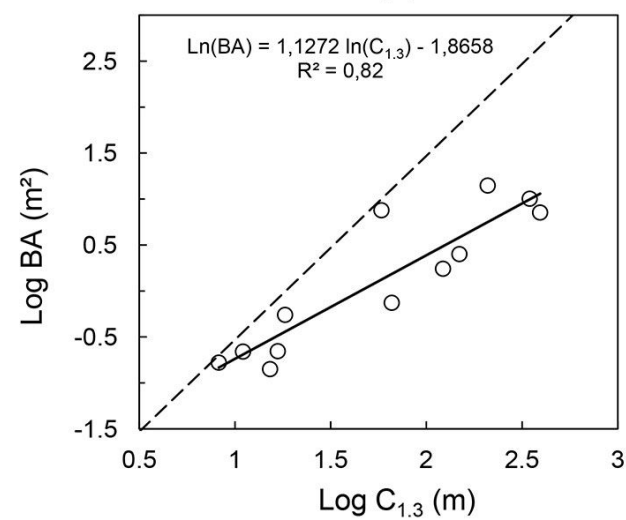

B

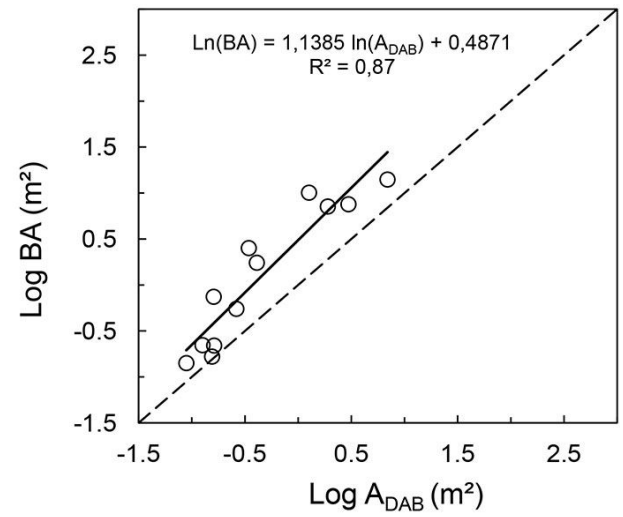


while the latter is the actual basal area of the tree. The relationship between the cross-sectional area above the buttress and the basa area at $1.3 \mathrm{~m}$ height $(B A)$ is crucial for practical applications, as it allows for the predic tion of the stand basal area of buttressed trees. The relatively strong relationships found in this study between the above parameters are displayed in Fig. 5. These results are consistent with the findings by Ngomanda et al. (2012), who measured the buttress perimeter with a wire. As there is visual evidence of heteroscedasticity, linear models were fit to the log-transformed variables. The plot of $B A$ versus $A_{\mathrm{DAB}}$ includes a $1: 1$ line, while the dashed line in the plot of $B A$ versus $C_{1.3}$ shows the relationship for a perfect circle.

\section{Discussion}

The estimation of forest biomass has received much attention over the past years. In spite of the increasing number of global forest biomass maps available, many basic questions on the determination of single tree biomass, volume or carbon still remain to be solved.

Large trees carry the largest variability in volume and biomass - in particular in tropical lowland rain forests - and exhibit considerable stem irregularities, most notably buttresses. Measuring the volume, biomass or carbon for these trees is evidently difficult and constitutes a considerable source of error when estimating forest above ground biomass and carbon stocks. In this study, we used a terrestrial laser scanner to scan 12 buttressed trees of different species in the Botanical Garden of Bogor, Indonesia in order to analyze the geometry and allometry of these highly irregular stems. Although the $3 \mathrm{D}$ analyses carried out on buttresses revealed new insights into their very irregular geometry, our small sample size does not allow the derivation of generalized allometric relationships for different tree species or dimensions. However, the methodological ap proach described in our study may easily be extended to a more comprehensive data sample, including larger numbers of trees per species, covering a wider range of diameters, and including trees grown-up within forest stands.

The changes in actual cross sections along the buttressed part of sampled trees follow highly variable patterns. For trees characterized by very high but slim buttresses, the diameter of the central solid stem is decreasing with increasing the cross-sectional area of buttresses (see e.g., tree \#2 and \#8 in Fig. 4). For other trees analyzed, like tree \#4 (Ficus albipila), \#9 (Ceiba pentandra) or \#1 (Koompassia excelsa), the solid stem (even if reduced in diameter) reaches down to the ground, contributing significantly to the lowest cross-sectional area.
We may conclude that the geometry of the buttress cross sections towards the tree base is much more complex than expected. To our knowledge, the geometric feature of cross sections of buttressed trees has not been described yet in this details. Indeed, our results contradict the assumption that a distinct stem becomes thinner towards the ground, laterally supported by buttresses (Mattheck 1998). In some cases, the concept of a distinct stem appears to dissolve towards the ground. This also means that the measurement protocol described by Picard et al. (2012, p. 68 and Fig. 4.6) for the calculation of buttress volume is not generally applicable, but holds for "simply buttressed" trees only.

Despite the small sample size analyzed, our results suggest that the relation between the cross-sectional area in $D A B$ height and the actual tree basal area measured at $1.3 \mathrm{~m}$ height is relatively strong $\left(\mathrm{R}^{2}=0.87\right)$ for a range of buttress morphologies and tree dimensions, regardless of the very different geometries observed in the cross-sectional areas. By means of relationships between $D A B$ and basal area, it would be possible to model the actual basal area of tropical forests including the buttressed trees. As the basal area is one of the most important variables in forestry, being highly correlated to total stand volume and biomass, knowledge about this variable would allow deriving models for fast volume approximations. For the analysis of the buttress allometry, we chose a general allometric model that allows the interpretation based on first principles and that could extend over the full possible range of data. The fitted power of the relationships between $C_{1.3}, A_{\mathrm{DAB}}$ and tree basal area was close to one, suggesting a nearly isometric scaling. However, the relation between the log-transformed tree basal area and crosssectional area at $D A B$ height showed a slightly non-linear trend, thus better results were obtained using a logarithmic function $\left(B A=1.5545 \cdot \ln \left(A_{\mathrm{DAB}}\right)+1.9434, \mathrm{R}^{2}=0.93\right)$.

The mean form factor of 1.53 we derived from the sampled trees gives an indication of the potential under-estimation of volume and biomass for the lower buttressed stem section. The buttressed lower stem section contains $153 \%$ of the volume of the cylindrical volume calculated based on the $D A B$.

The relation between $C_{1.3}$ and basal area showed a nearly linear trend. Besides the actual tree size, it should be noted that the $C_{1.3}$ is very much influenced by the number and direction of main buttresses that span the convex hull. In this study, trees having a low number of main buttresses tend to extend farther from the stem axis than those with more main buttresses.

Allometric relationships are commonly used for the biomass estimation of individual trees. According to Ngomanda et al. (2012), we expect that such allometric relationships can be derived with reasonable model accuracy also for irregularly shaped large trees, either using a buttress form factor (as introduced here) or by using the diameter above buttress and/or the length of the convex hull at $1.3 \mathrm{~m}$ height as input variables. However, any measurement taken from such trees in the field is difficult to obtain. Therefore, it is certainly worthwhile to look into potential measurement errors when developing allometric functions based on variables that are difficult to be measured.

Even if multiple scanning positions were necessary to avoid scan shadows, the applied TLS approach was easy to implement under the given conditions in a botanical garden. A single tree could be scanned in less than 35 min, including the time for scanner repositioning. The duration of a single scan with normal quality and high-angle resolution is 3:22 min. Pre-processing, co-registration and cleaning of the laser point clouds is office work, taking about half a day for highlycomplex tree geometries. The manual delineation of cross-sectional areas in $5 \mathrm{~cm}$ height intervals was the most time-expensive activity. However, considering that destructive sampling is not a viable alternative to research into the allometry of big-buttressed trees in a similar level of detail, the proposed method proves to be a useful and non-destructive approach that allows for a range of meaningful measurements.

In a dense tropical rain forest, however, the understory vegetation and lianas may hamper fast and easy scanning, especially if the multi-scan method is used. Under these conditions, data collection and pre-processing could be more complicated and time-consuming. Our approach of manual delineation of the cross sections turned out to be robust as compared with the existing algorithms for automated identification of non-convex shapes. The proposed method might help to convert diameters measured at different heights to a single standard reference height, not only in context of model application but also for model building. This allows estimating a stand basal area at a defined reference height for forest stands including buttressed trees.

Further research should be addressed to the relationships among variables that are relevant and feasible to measure in the field, e.g., the relation between $D A B$ and the tree basal area. The patterns observed in this study suggest that general allometric relations may exist for buttressed trees, though a confirmation based on a larger sample size is required.

\section{Acknowledgements}

This study was made possible through financial support from the German Academic Exchange Service (DAAD) which has been 
granted through the Higher Education Program HEP between the Agricultural University of Bogor IPB and the Faculty of Forest Sciences and Forest Ecology and SETSAF at Georg-August-Universität Göttingen. The study contributes to project B05 of the DFG funded CRC990 "Efforts". Data was collected in the context of a TLS course delivered at the Bogor Agricultural University IPB by Dominik Seidel and Nils Nölke. We thank our Bachelor students Michael Weber and Markus Klingemann for help in data collection and preparation. We are grateful to the Faculty of Forest Sciences and Forest Ecology in Göttingen for granting financial support. We thank PT. Datascrip and Zoller + Fröhlich GmbH in Jakarta for making available the laser scanner for our project We are also grateful to Didik Widyatmoko of LIPI for granting the permission to implement our study in the Bogor Botanical Garden.

\section{References}

Basuki TM, Van Laake PE, Skidmore AK, Hussin YA (2009). Allometric equations for estimating the above-ground biomass in tropical lowland Dipterocarp forests. Forest Ecology and Management 257: 1684-1694. - doi: 10.1016/j.foreco. 2009.01.027

Bauwens S (2013). Le LiDAR-t et la photogrammétrie pour modéliser des troncs irréguliers [Modeling irregular shaped tree with Terrestrial LiDAR and photogrammetry]. In: Proceedings of the International Conference "Utilisation du système LiDAR terrestre en écologie forestière (4ème édition)". Marseille (France) 8 Oct 2013. On-line presentation, pp. 24. [online] URL: http://hdl.handle.net/2268/159158

Chapman CA, Kaufman L, Chapman LJ (1998). Buttress formation and directional stress experienced during critical phases of tree development. Journal of Tropical Ecology 14: 341-349. - doi: 10.1017/S0266467498000261

Chave J, Andalo C, Brown S, Cairns MA, Chambers JQ, Eamus D, Folster H, Fromard F, Higuchi N, Kira T, Lescure JP, Ogawa BWNH, Puig H, Riera B, Yamakura T (2005). Tree allometry and improved estimation of carbon stocks and balance in tropical forests. Oecologia 145:87-99. - doi: 10.1007/s00442-005-0100-x

Clark DB, Clark DA (2000). Landscape-scale variation in forest structure and biomass in a tropical rain forest. Forest Ecology and Management 137: 185-198. - doi: 10.1016/S0378-1127 (99)00327-8

Clark DA (2002). Are tropical forests an important carbon sink? Reanalysis of the long-term plot data. Ecological Applications 12: 3-7. - doi: 10.1890/1051-0761(2002)012[0003:ATFAIC]2. $0 . \mathrm{CO} ; 2$

Clark DB, Kellner JR (2012). Tropical forest biomass estimation and the fallacy of misplaced concreteness. Journal of Vegetation Science 23: 1191-1196. - doi: 10.1111/j.1654-1103.2012.01 471.x
Crook MJ, Ennos AR, Banks JR (1997). The function of buttress roots: a comparative study of the anchorage systems of buttressed (Aglaia and Nephelium ramboutan species) and non-buttressed (Mallotus wrayi) tropical trees. Journal of Experimental Botany 48: 1703-1716. - doi: $10.1093 / \mathrm{jxb} / 48.9 .1703$

Cushman KC, Muller-Landau HC, Condit RS, Hubbell P (2014). Improving estimates of biomass change in buttressed trees using tree taper models. Methods in Ecology and Evolution 5 (6): 573-582. - doi: 10.1111/2041-210X.12187 Dean C (2003). Calculation of wood volume and stem taper using terrestrial single-image closerange photogrammetry and contemporary software tools. Silva Fennica 37 (3): 359-380. - doi: 10.14214/sf.495

Edelsbrunner H, Mücke EP (1994). Three-dimensional alpha shapes. ACM Transactions on Graphics 13 (1): 43-72. doi: 10.1145/174462.1566 35

Ennos AR (1993). The scaling of root anchorage. Journal of Theoretical Biology 161: 61-75. - doi: 10.1006/jtbi.1993.1040

Enquist BJ (2002). Universal scaling in tree and vascular plant allometry: toward a general quantitative theory linking plant form and function from cells to ecosystems. Tree Physiology 22: 1045-1064. - doi: 10.1093/treephys/22.15-16.10 45

Fehrmann L, Kleinn C (2006). General considerations about the use of allometric equations for biomass estimation on the example of Norway spruce in central Europe. Forest Ecology and Management 236: 412-421. - doi: 10.1016/j.for eco.2006.09.026

FAO (2004). National forest inventory: field manual template. Food and Agricukture Organization of the United Nations, Rome, Italy, pp. 84. [online] URL: http://www.fao.org/docrep/008/ae57 8e/ae578e00.htm

He Z, Tang Y, Deng X, Cao M (2013). Buttress trees in a 20 -hectare tropical dipterocarp rainforest in Xishuangbanna, SW China. Journal of Plant Ecology 6: 187-192. - doi: 10.1093/jpe/rtt 052

Henry M, Besnard A, Asante WA, Eshun J, AduBredu S, Valentini R, Bernoux M, Saint-André L (2010). Wood density, phytomass variations within and among trees, and allometric equations in a tropical rainforest of Africa. Forest Ecology and Management 260: 1375-1388. - doi: 10.1016/j.foreco.2010.07.040

Kazhdan M, Bolitho M, Hoppe H (2006). Poisson surface reconstruction. In: Proceedings of the "Eurographics Symposium on Geometry Processing" (Polthier K, Sheffer A eds). Cagliari (Italy) 26-28 Jun 2006, pp. 61-70. [online] URL: http://faculty.cs.tamu.edu/schaefer/teaching/689 Fall2006/poissonrecon.pdf

Mattheck C (1998). Design in nature: learning from trees. Springer Science \& Business Media, Springer-Verlag, Berlin, Germany, pp. 276. [online] URL: http://books.google.com/books?id=X $\mathrm{NZ} 3$ G7gMwC

Mehedi AH, Kundu C, Chowdhury Q (2012). Pat- terns of tree buttressing at Lawachara National Park, Bangladesh. Journal of Forest Research 23 (3): 461-466. - doi: 10.1007/s11676-012-0285-x Metcalf CJE, Clark JS, Clark DA (2009). Tree growth inference and prediction when the point of measurement changes: modelling around buttresses in tropical forests. Journal of Tropical Ecology 25: 1-2. - doi: 10.1017/S0266467408 005646

Mindawati N, Hendromono HM, Toma T, Morikawa Y, Ngaloken GA (2004). Tree trunk volume of Shorea species: case study in Darmaga and Haurbentes research forest in West Java, Indonesia. Journal of Forestry Research 1 (1) 17-24. [online] URL: http://ejournal.forda-mof. org/ejournal-litbang/index.php/IJFR/article/view/ 483

Newbery DM, Schwan S, Chuyong GB, Van der Burgt XM (2009). Buttress form of the central African rain forest tree Microberlinia bisulcata, and its possible role in nutrient acquisition. Trees 23: 219-234. - doi: 10.1007/s00468-008-0270-3 Ngomanda A, Mavouroulou QM, Obiang NLE, Iponga DM, Mavoungou JF, Lépengué N, Picard N, Mbatchi B (2012). Derivation of diameter measurements for buttressed trees, an example from Gabon. Journal of Tropical Ecology 28: 299-302. - doi: 10.1017/S0266467412000144 Niklas KJ (1994). Plant allometry: the scaling of plant form and process. University of Chicago Press, Chicago, IL, USA, pp. 395. [online] URL: http://books.google.com/books?id=Wiy3fL_ofTEC

Niklas KJ (2004). Plant allometry: is there a grand unifying theorem? Biological Reviews 79: 871889. - doi: 10.1017/S1464793104006499

Niklas KJ (2013). Biophysical and size-dependent perspectives on plant evolution. Journal of Experimental Botany 64: 4817-4827. - doi: 10.1093/jxb/ers379

Nogueira EM, Nelson BW, Fearnside PM (2006). Volume and biomass of trees in central Amazonia: influence of irregularly shaped and hollow trunks. Forest Ecology and Management 227: 14-21. - doi: 10.1016/j.foreco.2006.02.004 Parresol BR (1999). Assessing tree and stand biomass: a review with examples and critical comparisons. Forest Science 45 (4): 573-593. [online] URL: http://www.ingentaconnect.com/ content/saf/fs/1999/00000045/00000004/art0001 4

Phillips OL, Malhi Y, Vincety B, Baker T, Lewis SL, Higuchi N, Laurance WF, Nunez Vargas P, Vasquez Martinez R, Laurance S, Ferreira LV, Stern M, Brown S, Grace J (2002). Changes in growth of tropical forests: evaluating potential biases. Ecological Applications 12: 576-587. doi: 10.1890/1051-0761(2002)012[0576:CIGOT F]2.0.CO;2

Picard N, Saint-André L, Henry M (2012). Manual for building tree volume and biomass allometric equations: from field measurement to prediction. Food and Agricultural Organization of the United Nations, Rome, Italy, and Centre de Coopération Internationale en Recherche Agronomique pour le Développement, Montpellier, 
France, pp. 215.

Pilli R, Anfodillo T, Carrer M (2006). Towards a functional and simplified allometry for estimating forest biomass. Forest Ecology and Management 237: 583-593. - doi: 10.1016/j.foreco.2006 10.004

R Core Team (2013). R: a language and environment for statistical computing. $\mathrm{R}$ foundation for statistical computing, Vienna, Austria. [online] URL: http://www.r-project.org/

Richards PW (1952). The tropical rain forest Cambridge University Press, Cambridge, UK, pp. 450.

Richter W (1984). A structural approach to the function of buttresses of Quararibea asterolepis. Ecology 65 (5): 1429-1435. - doi: 10.2307/19 39123

Saner P, Loh YY, Ong RC, Hector A (2012). Carbon stocks and fluxes in tropical lowland dipterocarp rainforests in Sabah, Malaysian Borneo. PloS One 7 (1): e29642. - doi: 10.1371/journal. pone.0029642

Slik JWF, Aiba SI, Brearley FQ, Cannon CH, Forshed O, Kitayama K, Nagamasu H, Nilus R, Payne J, Paoli G, Poulsen AD, Raes N, Sheil D, Sidiyasa K, Suzuki E, Van Valkenburg JLCH (2010). Environmental correlates of tree biomass, basal area, wood specific gravity and stem density gradients in Borneo's tropical forests. Global Ecology and Biogeography 19: 50-60. doi: 10.1111/j.1466-8238.2009.00489.x

Smith AP (1972). Buttressing of tropical trees: a descriptive model and new hypotheis. American Naturalist 106: 32-46. - doi: 10.1086/282749

Stephenson NL, Das AJ, Condit R, Russo SE, Baker PJ, Beckman NG, Coomes DA, Lines ER, Morris WK, Ruger N, Alvarez E, Blundo C, Bunyavejchewin S, Chuyong G, Davies SJ, Duque A, Ewango CN, Flores O, Franklin JF, Grau HR, Hao Z, Harmon ME, Hubbell SP, Kenfack D, Lin Y, Makana J, Malizia A, Malizia LR, Pabst RJ, Pongpattananurak N, Su S, Sun I,
Tan S, Thomas D, Van Mantgem PJ, Wang X, Wiser SK, Zavala MA (2014). Rate of tree carbon accumulation increases continuously with tree size. Nature 507 (7490): 90-93. - doi: 10.1038/nature12914

West GB, Brown JH, Enquist BJ (1997). A general model for the origin of allometry scaling laws in biology. Science 276: 122-126. - doi: 10.11 26/science. 276.5309 .122

West GB, Brown JH, Enquist BJ (1999a). The fourth dimension of live: fractal geometry and allometric scaling of organisms. Science 284: $167-$ 169. - doi: 10.1126/science.284.5420.1677

West GB, Brown JH, Enquist BJ (1999b). A general model for the structure and allometry of plant vascular systems. Nature 400: 664-667. - doi: $10.1038 / 23251$

Zianis D, Mencuccini M (2004). On simplifying allometric analyses of forest biomass. Forest Ecology and Management 187: 311-332. - doi: 10.1016/j.foreco.2003.07.007 